УДК 37.013.73+37.01

DOI https://doi.org/10.32837/apfs.v0i32.1020

O. А. Гончаренко
ORCID ID: https://orcid.org/0000-0002-2710-6521
доктор piлософських наук, дощент,
доцент кафедри психологї̈, педагогіки та соиіально-економічнх дисииплін Національної академії
Державної прикордонної служби України імені Богдана Хмельнищького

\title{
ФІЛОСОФІЯ ОСВІТИ - ЦЕ НЕ ФІЛОСОФІЯ?
}

Постановка проблеми. Чи дійсно філософія освіти є філософською наукою? Це питання все частіше лунає серед науковців, галуззю досліджень яких є філософія освіти.

Аналіз останніх досліджень. Джеймс Скотт Джонстон у книзі «Проблеми у філософії освіти» (2019) доводить, що питання, які намагається з'ясовувати філософія освіти, є не філософськими, а педагогічними [11, с. 109]. Подібну думку висловлює в статті «Філософія освіти як філософія: метафілософський підхід» (2007) Джордж Поллак. Він стверджує, що багато відомих філософів мали міркування на тему освіти, проте вони не були філософськими в точному розумінні цього слова. До того ж аудиторії, якій вони пропонували свої міркування, не була потрібна філософська освіта [14, с. 250]. Аналогічної позиції дотримуються автори статті «Філософія освіти» в Стенфордській філософській енциклопедії. Гарві Сігел, Деніс Чарльз Філіпс, Імон Каллан пишуть, що роздуми відомих філософів на тему освіти мають мало або зовсім не мають філософського змісту. Попри це, їхні твори часто розглядаються як унесок до філософії освіти [15].

Зокрема, не зовсім філософським, на думку Джонстона, є питання навчання, яке, на його погляд, є радше епістемічним, ніж (строго) моральним [11, с. 112]. У цьому контексті питання Менона до Сократа про можливість навчання доброчесності дослідник уважає неоригінальним i, відповідно, не вартим того, щоб філософія освіти поверталася до нього з історичної перспективи [11, с. 130].

Проте варто зважити на той факт, що Платон порушив питання про можливість навчання доброчесності у зв'язку з питанням визначення доброчесності. Сократ не знав, чи можна навчитися доброчесності, тому що не знав, що таке доброчесність [13, с. 71a]. Платон намагався визначити доброчесність розрізненням їі значень, тобто істинної та оманливої подоби [4, с. 85]. До цього філософа спонукали софісти, які переконували, що людина може придбати доброчесність наполегливістю та навчанням. Платон же вважав, що людина не може навчитись доброчесності, тому що вона не передається від людини до людини.

До розрізнення значень доброчесності вдавалися й інші філософи. Сенека відрізнив просту до- брочесність від вигадливої науки [6, с. 399], Рене Декарт - справжню доброчесність від удаваної [2, с. 91]. У такий спосіб філософи протистояли спотворенню уявлень у суспільстві про доброчесність. Пов'язаність доброчесності з навчанням вплинула згодом на розрізнення філософами значень освіти. Фрідріх Ніцше відрізнив істинну освіту від облудної примари [12, с. 40], Теодор Адорно - освіту від напівосвіти [1, с. 129]. У такий спосіб філософи критикували суспільство за вибір освітнім ідеалом пристосування й адаптацію. Очевидно, філософи завжди мали філософську ідею освіти, яка є протилежною потребі виживання.

Постановка мети. У цій статті ми спробуємо спростувати тезу Джонстона про те, що питання Менона до Сократа про можливість навчання доброчесності не є філософським. Для цього ми спочатку доведемо, що це питання є питанням етики, теорії пізнання та метафізики, а потім продемонструємо його постійні оновлення у філософії. Ми не маємо наміру заперечити, що це питання не може бути педагогічним, проте хочемо довести, що воно є питанням філософії. Можливо, це посприяє ясності з визначенням філософії освіти як філософської науки.

Виклад основного матеріалу. 1. Полеміка Платона проти софістів. Софісти за професією не всі були філософами. Вони часто були педагогами. Софісти навчали молодь досягненню успіху в громадянському житті. Вони навчали згідно з духом часу. Філософи дорікали софістам за комерціалізацію знання та критикували їх за релятивізм. Особливо гостро дискутував із софістами Платон. Він намагався відрізнити їх дискурс від дискурсу філософів. Причин для цього було декілька.

Доброчесність як умілість / досконалість.

Софісти мали примітивне уявлення про доброчесність. Вони зводили їі до компетентності, яка мала допомогти людині в досягненні конкретних цілей і реалізації визначених інтересів. Їх турбувало не те, що істинне, а те, що дієве. Софісти вірили, що людину можна навчити доброчесності, якщо примушувати її виконувати все так, як має бути. Тобто доброчесність вони вважали результатом насилля. Наприклад, Протагор, за Платоном, розумів під доброчесністю тямущість у домашніх справах та громадських питаннях, а також «уміння вміло 
діяти і говорити в справах, що стосуються держави» [5, с. 116]. Саме завдяки цій громадянській умілості Протагор обіцяв зробити з людей добрих громадян. Набуття людиною такої доброчесності він порівнював із покаранням злочинців (карати 3 метою запобігти злу, на пострах) [5, с. 121].

Платон мав складне уявлення про доброчесність. Він розумів іiі як досконалість, що за будь-яких обставин ставала б у пригоді людині. Цю досконалість філософ пов'язував з умінням людини робити правильний вибір у житті, щоб ніщо не змусило її чинити не за велінням розуму. Тому доброчесність він ототожнював із розумом, знанням та мудрістю. Платон вірив, що людина здатна сама вдосконалити свій розум і характер. Тобто доброчесність він розглядав як результат самовдосконалення. Наприклад, Платон вустами Сократа твердив, що «творити щось нижче своїх можливостей - це не що інше, як неуцтво, а творити щось понад свої можливості мудрість» [5, с. 151]. Якщо людина матиме можливість вибору, то вона не обере зло.

Доброчесність як відносне / безвідносне благо.

Софісти розуміли доброчесність як цілком відносне благо, різне для чоловіка і жінки, дитини й людини похилого віку. Вони стояли на засадах релятивізму, тому переймалися тим, як пристосувати людину до наявного стану життя в суспільстві та як навчити ї̈ діяти щодо нього. Наприклад, Менон, за Платоном, твердив, що доброчесностей є багато й усі вони різні. Так, доброчесність чоловіка полягає в умінні порядкувати в державі, а доброчесність жінки - у домі [13, с. 71е].

Платон розумів доброчесність як єдине благо для всіх людей та в усі часи. Він стояв на позиції абсолютизму. Він турбувався про те, щоб людина змогла самостійно жити за будь-яких обставин. Вустами Сократа Платон говорив, що людина повинна не зважати на обставини, а коритися лише власному розуму, який сам вирішує, що добре. Для Платона доброчесність була чимось вічним, що не народжується і не вмирає, «що прекрасне в усьому, завжди, всюди й для всіх» [4, с. 83].

Доброчесність як знання / незнання.

Софісти вважали, що доброчесність є створеним предметом, тому її можна передати іншим. Цей процес передбачає, наприклад, за Протагором, спочатку повчання батьків на прикладах різних вчинків у ранньому дитинстві, потім турботу вчителів про виховання гарних манер у школі, а згодом примус держави до знання й дотримання її законів [5, с. 123]. Для софістів важливо, щоб людина знала, як себе поводити за певних обставин, тому вони намагались дати людині готове знання, істинність якого могла бути й сумнівною. У такому разі людина втрачала свободу для свого становлення.

Платон уважав, що доброчесність не є створеним предметом, тому їі не можна передати іншим. Платон вустами Сократа твердив, що «добрі люди стають добрими завдяки не людській турботливості» [5, с. 124], а прагненню до досконалості. Він був переконаний, що доброчесності не можна навчитися. Для прикладу він наводив Фукідіда та його синів. Усьому, що вимагає витрат на навчання, Фукідід своїх синів навчив, але того, як стати добрими людьми (а на це витрачатися не потрібно), він їх не навчив (якщо цьому взагалі можна навчитися) [13, с. $94 \mathrm{~d}]$.

Доброчесність як відтворення / пізнання.

Софісти пропонували навчати доброчесності пасивно. Вони орієнтувалися на навчання не того знання, яке є істинним, а того, що є дієвим у визначених практиках життя. Навчання доброчесності вони розглядали як передання готового знання у формі відповідей учителя на запитання учнів. Софісти вважали, що доброчесності можна навчитися через заучування та наслідування. Наприклад, Протагор важливу роль у процесі навчання доброчесності відводив знанню поезії [5, с. 134]. Знайомство з поезією він пропонував розпочинати одразу після навчання дітей читанню, коли вони починають розуміти написане так, як раніше мовлене слово. Учителі мають заохочувати молодь до читання творів хороших поетів та вивчення їх напам'ять. Похвали й прославляння славетних мужів у поезії мають, на погляд Протагора, мотивувати молодь до наслідування [5, с. 122]. Визначенням знання поезії важливою частиною освіти Протагор позбавляв навчання доброчесності особистісного підходу, за якого людина здатна лише до відтворення нав'язаних ззовні образів доброчесності.

На противагу софістам Платон пропонував активно досягати доброчесності. Він виходив 3 усвідомлення браку знання та прагнення досягти його своїми зусиллями. Досягнення доброчесності Платон пов'язував лише зі ставленням учителем запитань учням, оскільки готовим знанням не володіє ніхто. Розмови про поезію нагадували Платону гулянки простакуватого і невибагливого товариства, в якому одні кажуть, що поет мав щось одне на думці, а інші - щось інше, або розмовляють на тему, в якій нічого не можуть довести. Він уважав, що освічені люди здатні спілкуватися між собою своїм голосом і своїми словами без чужої допомоги. Саме таких людей повинні, на його переконання, більше наслідувати юнаки i, відклавши в сторону поетів, власними зусиллями вести бесіду один з одним, щоб пізнавати істину й самих себе [5, с. 141]. Пошук істини Платон пов'язував із пригадуванням людиною минулого життєвого досвіду, закладеного в душі до її нового втілення, адже шукати і пізнавати - це і є пригадувати [13, с. $81 \mathrm{~d}]$.

Доброчесність для навчання / життя.

Софісти претендували на те, що можуть не лише краще, а й у досить короткий термін навчити 
будь-яку людину доброчесності. На їхне переконання, таке навчання може відбуватись лише в юнацькому віці й тільки заради освіти. Коли ж людина в зрілому віці прагнула до вдосконалення, то це виглядало для них сміховинно, зовсім не по-чоловічому й заслуговувало на побиття палицею.

Платон не розглядав похилий вік як перешкоду для вдосконалення людини. Кожний вік, на його переконання, є достойним для навчання доброчесності.

Як бачимо, причин для протистояння в Платона було достатньо. Усі вони стосувалися відмінного розуміння доброчесності та ії досягнення: софісти доброчесність визначали як громадянську умілість, Платон - як людську досконалість; софісти розуміли доброчесність як відносне благо, Платон - як безвідносне; софісти претендували на навчання доброчесності, Платон відкидав таку можливість; софісти навчали доброчесності заучуванням та наслідуванням, Платон у цьому процесі віддав перевагу пізнанню та пошуку істини; софісти ефективним для навчання доброчесності вважали вік дозрівання, Платон не бачив у віці перешкод для досягнення доброчесності.

Отже, софісти і Платон вкладали в поняття доброчесності різні значення: софісти - педагогічне, Платон - філософське. Доброчесність софістів це компетентність, яка допомагає пристосуватися до певних умов життя. Доброчесність Платона це етична чеснота, яка допомагає людині в житті за будь-яких умов. Доброчесності софістів можна навчитися в певний період життя, якщо мати певні здібності та бажання розвитку. Доброчесність Платона можна пізнавати протягом життя, якщо намагатися пригадати своє попереднє існування. Доброчесність софістів Платон називав оманливою подобою, тому що навчання її допоможе людині лише знати щось, проте не стати кращою та розумнішою. Полемікою проти софістів Платон намагався відстояти низку важливих для філософії питань: для етики - питання про доброчесність як моральну досконалість, безвідносне благо та знання; для теорії пізнання - про знання як пошук істини; для метафізики - про буття як змінне і незмінне, реальне й ідеальне.

2. Полеміка філософів проти педагогів. У кожен момент історії можна знайти філософа, який намагався поновити питання Менона до Сократа у своїх працях. У такий спосіб він протиставляв педагогічним імітаціям в освіті її античний ідеал.

Питання про доброчесність як знання актуалізував у своїй творчості Сенека. Справжнє благо філософ ототожнив зі знанням, а зло - із незнанням. Кмітлива й передбачлива людина (з огляду на обставини) відкидає щось одне на користь іншого. Якщо вона людина висока й незламна, то те, що відкидає, того не лякається, а те, що вибирає, тим не захоплюється [6, с. 122]. Доброчесність для
Сенеки є зневагою до всього випадкового й мінливого в житті, бо «не блукає лише той, хто на стійкій засаді» [6, с. 130].

Сполучав доброчесність зі знанням Цицерон. Найвищим благом філософ визначав досягнення того, що є за природою першим і бажаним самим по собі. А таким, на його думку, є те, що міститься в самій душі та в доброчесності. Під доброчесністю Цицерон розумів усе моральне, пристойне та правильне. Досконалу доброчесність він пов'язував із розумом. Таку доброчесність Цицерон називав істинним розумом, а її протилежність - зіпсутістю. Зіпсутість філософ протиставляв не лише розуму, а й спокою душі й життя. «ЖАити» для мудрої та освіченої людини означає, за Цицероном, те саме, що й «мислити» [10].

Питання про знання як пошук істини розвинув після Платона Аристотель. Філософ розрізняв справжню мудрість від мудрості тільки удаваної. Справжня мудрість - це справа філософів. Вони прагнуть істини та вміють виявляти брехню. 3 одного боку, вони вміють висловлювати власні думки, з іншого - уміють чути думки інших. Удавана мудрість - це справа софістів. Вони прагнуть користі від удаваної, несправжньої мудрості. Для них важливо міркувати заради суперечки та прагнення перемогти. Аристотель спростовував удавані докази софістів на підставах логіки [8].

Мав сумнів щодо навчання доброчесності Сенека. Він уважав, що здоровий глузді не позичиш, і не купиш. А коли б він і продавався, то зовсім не відомо, чи віднайшовся б на нього покупець [6, с. 111]. Сенека міркував, що людина знатна сама розвиватись і вчитись пізнавати істину. Лише так людина буде мати знання про те, що корисне і шкідливе для неї. Тому він писав, що одна річ - пам'ятати, а інша - знати. Бо пам'ятати - це пильнувати в пам'яті щось чуже, дане на збереження, а знати - це засвоювати, не тримаючись сліпо зразка, не озираючись раз у раз на наставника [6, с. 127]. Визначенням комунікації підгрунтям процесу пізнання Сенека підкреслював значення особистісного підходу в досягненні доброчесності. Важливим у цьому процесі він уважав дружбу. Філософ уважав, що живий голос і товаришування 3 розумними людьми допомагає перейняти від них не стільки настанови для життя, скільки власний спосіб життя.

Традиційне розуміння знання відкидав Аврелій Августин. Істинним навчанням він визначав споглядання внутрішньої істини відповідно до власних здібностей, а помилковим - виклад наук за посередництва слів. Філософ твердив, що люди називають учителями тих, хто зовсім ними не є, тому що між моментом мовлення і моментом пізнання немає жодних проміжків. Лише тому, що внутрішнє учіння йде слідом за нагадуваннями того, хто говорить, видається, наче навчаються зовнішньо 
в того, хто пригадував [9, с. 10]. Це означає, що знання не можна передати за допомогою усного чи писемного мовлення, а лише пізнати в самому собі, бо тільки всередині людини живе істина.

Освітній ідеал філософії Античності набув розвитку у творчості Мішеля Монтеня. Філософ критикував ученість за позичену, вижебрану мудрість. Він говорив: «Якби людині вдалось стати вченою чужою вченістю, то мудрою вона змогла б стати тільки власною мудрістю» [3, с. 154]. Тому знання він оцінював не так високо, як розум, бо розум може обійтись без знань, а знання без розуму - ні. Наповнені голови ще не є розумними.

Книжковим студіям протиставив науку, яку можна здобути в самому собі або у великій книзі світу, Рене Декарт. Книжкові студії - це умоглядна філософія, її викладають у школах. Практична філософія - це наука, яка робить людей мудрішими і вправнішими [2, с. 87-88]. У використанні власного розуму в усій повноті від народження і до смерті Декарт убачав можливість для людини стати доброчесною насправді, а не удавано чи згідно з чиєюсь думкою [2, с. 90].

Єдиною істинною вітчизною освіти Фрідріх Ніцше вважав античну Грецію. Освіту філософ порівнював із виробництвом потрібних для використання людей. Таку освіту він називав швидкою, тому що вона дозволяє людині споживати стільки культури, скільки потрібно в інтересах наживи. Така освіта, на його думку, є оманливим привидом модної фікції культури «сучасності», який із глибокою ненавистю відштовхує від себе істинну освіту, пропонуючи замість цього лиш дріб' язкову вченість [12, с. 37].

Питання про буття як злінне $і$ незлінне, реальне й ідеальне поновив у своїх працях і Ніцше. Освітою він називав несвідоме відчуття метафізичної єдності всіх речей на великому прикладі природи та одночасне заспокоєння перед її вічною постійністю і необхідністю. Така освіта дає людині крила, що підносять її до царства незмінних праобразів усіх речей [12, с. 114].

Схожі міркування висловив Петер Слотердайк. Ранні школи філософ порівняв із базовими таборами спонтанного розвитку внутрішньої вертикальності через амбітні задуми їхніх очільників підняти своїх учнів до верхівок гір завдяки орієнтації школи на «завдання, трансцендентні їі заняттям». Більш пізні школи нагадують йому базові табори навчання з переміщення всередині них через спротив їхніх очільників уявленню про те, що за межами школи може існувати щось реальне, та відмову від трансцендентальних претензій [7, с. 77].

Продемонстрованих прикладів оновлення у філософії питання Менона до Сократа достатньо, щоб переконатися в протиставленні філософами власної (філософської) ідеї освіти її педагогічним пропозиціям. Полеміку філософів проти педагогів можна вважати продовженням полеміки Платона проти софістів. Вони, як і Платон, намагались відстояти важливі для філософії питання.

Зведенням доброчесності до знання філософи пов'язували зло 3 незнанням, а усе правильне й пристойне - зі знанням. Вони переконували, що зло полягає не в речах, а в міркуваннях щодо них, тому досягти досконалості можна завдяки розумуванню. Протиставленням пам'яті та знання філософи спростовували уявлення про знання як сукупність думок, які можна передати в готовому вигляді. Вони вважали, що знання є цінним лише тоді, коли створюється самостійно. Розглядом буття (як змінного й незмінного, реального та ідеального) філософи наполягали на практиці незацікавленості пізнання. Протиставляючи неупереджений пошук знань суспільному меркантилізму, вони нагадували, що лише запаморочливий стрибок у світ абсолютних цінностей може допомогти людині перевершити саму себе. Оновленням питання Менона до Сократа філософи мали намір не запропонувати щось нове в його відповіді, а тільки наголосити на ефекті від філософської практики в житті.

Висновки і перспективи подалыших досліджень. Питання Менона до Сократа про можливість навчання доброчесності є філософським, тому що є питанням етики, теорії пізнання та метафізики. Постійні оновлення цього питання у філософії переконують у тривалому протистоянні протилежних ідей формування людини - педагогічної та філософської. Звісно, це питання може бути педагогічним, проте саме цим питанням філософія намагалась від античності до сьогодення відстояти важливість справжнього та наполегливого вправляння людини в житті. Оскільки це питання $є$ філософським, то, очевидно, воно варте того, щоб філософія освіти поверталася до нього з історичної перспективи. Імовірно, саме в цьому питанні криється філософська ідея освіти. Варто лише бути більш уважним до розуміння філософії як вправи, яка готує до життя.

\section{Jimepamypa}

1. Адорно Т. Теорія напівосвіти. Філософія освіти. Philosophy of Education, 2017. № 1 (20). C. 128-152.

2. Декарт Р. Дискусія про метод, щоби добре спрямовувати свою рацію й шукати істину в науках. Метафізичні твори / пер. $з$ фр. і лат. В. Андрушко, А. Баумейстер, С. Гатальська, О. Хома; відповід. Ред. О. Хома. Харків, 2020. С. 45-98.

3. Монтень М. Проби. Книга перша / перекл. 3 фр. А. Перепадя. Київ : Дух і Літера, 2005. 356 с.

4. Платон. Бенкет / перекл. 3 давньогрецької і коментарі Уляна Головач, вступна стаття Джованні Реале. Львів : Видавництво Українського католицького університету, 2005. 178 с.

5. Платон. Протагор. Діалоги / перекл. з давньогр. Київ : Основи, 1999. С. 108-154.

6. Сенека. Моральні листи до Луцілія / пер. А. Содомора. Львів : Апріорі, 2018. 552 с. 
7. Слотердайк П. Ти мусиш змінити своє життя. Філосоpis ocвimu. Philosophy of Education, 2014. № 1(14). C. 76-95.

8. Aristotle. On Sophistical Refutations. URL: The Internet Classics Archive | On Sophistical Refutations by Aristotle (mit.edu) (дата звернення: 28.09.2021)

9. Augustine St. De Magistro. URL: On the De Magistro of St. Augustine - 1938 (erhfund.org) (дата звернення: 28.09.2021)

10. Cicero M.T. The Academic Questions, Treatise De Finibus. Tusculan Disputation / transl. C.D. Yonge. London : George Bell and Sons York Street Covent Garden, 1875. 600 p. URL: The Academic Questions (gutenberg. org) (дата звернення: 29.09.2021)

11. Johnston J.S. Problems in Philosophy of Education. A Systematic Approach. London; New York; Oxford; New Delhi; Sydney : Bloomsbury Academic, 2019. 250 p. URL: (1) (PDF) Problems in Philosophy of Education | James Scott Johnston - Academia.edu (дата звернення: 14.09.2021)

12. Nietzsche F. On the Future of Our Educational Institutions. Homer and Classical Philology / transl., with introd. J. M. Kennedy. Edinburgh and London: T. N. Foulis 13\&15 Frederick Street. URL: The Project Gutenberg eBook of On the Future of Our Educational Institutions and Homer and Classical Philology, by Friedrich Nietzsche. (дата звернення: 28.09.2021)

13. Plato. Meno. Plato in Twelve Volumes, Vol. 3 translated by W.R.M. Lamb. Cambridge, MA, Harvard University Press; London, William Heinemann Ltd. 1967. URL: Plato, Meno, section 70a (tufts.edu) (дата звернення: 14.09.2021)

14. Pollack G. Philosophy of Education as Philosophy: a Metaphilosophical Inquiry. Educational Theory. 2007. Vol. 57 (3). p. 239-260. URL: (PDF) Philosophy of Education as Philosophy: A Metaphilosophical Inquiry George Pollack - Academia.edu (дата звернення: 14.09.2021)

15. Siegel H., Phillips D.C., Callan E. Philosophy of Education. Stanford Encyclopedia of Philosophy / pr. ed. Ed. N. Zalta. Stanford University. 2018. URL: Philosophy of Education (Stanford Encyclopedia of Philosophy) (uva. nl) (дата звернення: 14.09.2021)

\section{Анотація}

Гончаренко О. А. Філософія освіти - це не філософія? - Стаття.

У статті порушено проблему визначення філософії освіти як філософської науки. Головним чином звернено увагу на твердження сучасних американських учених про те, що питання філософії освіти є не філософськими, а педагогічними. 3 огляду на це, виокремлено твердження Джеймса Скотта Джонстона в книжці «Проблеми у філософії освіти» (2019) про те, що питання Менона до Сократа про можливість навчання доброчесності не $є$ філософським, тобто $є$ не досить важливим для філософії освіти. Проте Платон порушив питання про можливість навчання доброчесності у зв'язку з питанням визначення доброчесності. Сократ не знав, чи можна навчитися доброчесності, тому що не знав, що таке доброчесність. У статті спростовується це твердження науковця та доводиться, що питання Менона до Сократа є питанням філософії. У першій частині статті проаналізовано полеміку Платона проти софістів у формі низки протиставлень: доброчесність як умілість / досконалість, доброчесність як відносне / безвідносне благо, доброчесність як знання / незнання, доброчесність як відтворення / пізнання, доброчесність для навчання / життя. Виявлено, що полемікою проти софістів Платон намагався відстояти важливі для етики, теорії пізнання та метафізики питання. У другій частині статті на прикладі праць Аристотеля, Сенеки, Цицерона, Аврелія Августина, Мішеля Монтеня, Рене Декарта, Фрідріха Ніцше, Петера Слотердайка продемонстровано постійні оновлення в історії подібної полеміки філософів із педагогами. 3'ясовано, що цим оновленням філософи намагались відстояти античну ідею освіти та показати потенціал філософії в широкому розумінні у формуванні людини. Зроблено висновок, що питання Менона до Сократа є питанням філософії, тому запропоновано в пошуках визначення філософії освіти його не відкидати, а вважати головним, оскільки саме в ньому можна розкрити освітній потенціал філософії.

Ключові слова: філософія, філософія освіти, філософська ідея освіти.

\section{Summary}

Honcharenko O. A. Philosophy of education is philosophy? - Article.

The paper rises the problem of defining philosophy of education as a philosophical study. In particular, the author focuses her attention on the statements of the contemporary American scholars who believe that, in fact, issues of philosophy of education are not a matter of philosophy, but of pedagogy. In this regard, she analyses James Scott Johnston's book "Problems in Philosophy of education" (2019). The article disproves Johnston's statements that Menon's question to Socrates about the possibility of teaching virtue is not philosophical, and therefore not important for philosophy of education. However, Plato raised the question about learning of virtue in regards with the definition of virtue. Socrates did not know whether it was possible to learn virtue, because he did not know what virtue was. The first part of the article analyses Plato's controversy against the Sophists in the form of a number of oppositions: virtue as a skill / proficiency, virtue as relative / absolute good, virtue as knowledge / ignorance, virtue as reproduction / cognition, virtue for learning / life. It was found that by arguing against the Sophists, Plato tried to advocate issues which were important for ethics, theory of knowledge and metaphysics. The second part of the article exemplifies by the works of Aristotle, Seneca, Cicero, Aurelius Augustine, Michel Montaigne, Rene Descartes, Friedrich Nietzsche, Peter Sloterdijk constant updates of such polemics between philosophers and teachers throughout history. By means of this update, philosophers tried to support the ancient idea of education and demonstrate the potential of philosophy in human formation. The author concludes that Menon's question to Socrates is a matter of philosophy. In addition, she suggests not to reject it while searching the definition of philosophy of education as a philosophical study, but on the contrary to consider it the main one. Because it can reveal the educational potential of philosophy.

Key words: philosophy, philosophy of education, philosophical idea of education. 